\title{
The Judgment of the Supreme Court sentencing Spain for failing to duly comply with the Council Decisions (EU) 2015/1523 and 2015/1601 on international protection for the benefit of Italy and Greece (STS 2546/2018, 9 July 20I8)
}

\author{
Eduardo JIMÉNEZ PINEDA*
}

\begin{abstract}
This note analyses the Judgment of the Supreme Court of 9 July 2018 sentencing Spain for failing to duly comply with the Council Decisions (European Union, hereinafter EU) establishing provisional measures in the area of international protection for the benefit of Italy and Greece, in other words, the Council Decisions 2015/1523 of I4 September 2015, OJ 2015 L 239/146, and 2015/160I of 22 September 2015, OJ 2015 L 248/48, establishing the legal regime to relocate in other EU Member States the thousands of asylum seekers who massively arrived in Italy and Greece since 20I4. In this sense, the association Associació de support a stop mare mortum appealed the rejection by administrative silence of a request of 21 April 2017 and sought the Spanish Government to immediately accomplish its obligations of relocating applicants of international protection, at least, in the measure of the quotas established for Spain by the aforesaid Decisions. Despite the lack of due cooperation between the European Union Member States, even Italy and Greece, the Supreme Court decided, in accordance with the two Decisions and the acquis communautaire, that Spain has partly breached its administrative obligations provided by the EU Decisions and, consequently, it shall continue processing the applications of international protection according to the Decisions and future agreements that the European Institutions may adopt.
\end{abstract}

Keywords: relocation, asylum seekers, Supreme Court's Judgment, Council Decision (EU) 2015/1523, Council Decision (EU) 2015/160I, principle of solidarity.

\section{(A) INTRODUCTION}

On 9 July 2018 the Supreme Court, concretely the Fifth Section of its ContentiousAdministrative Chamber, delivered the Judgment 2546/20I8 in answer to the appeal made, on behalf of the Associació de support a stop mare mortum, against the rejection by administrative silence of a request of 2I April 2017 for the Spanish Government to immediately fulfil its obligations of relocating applicants of international protection. Those obligations were established by the Council Decision (EU) 2015/1523 of I4 September 2015, OJ 2015 L 239/146, and the Council Decision (EU) 2015/160I of 22 September 2015, OJ 2015 L 248/48, ${ }^{2}$ which were

PhD Candidate in Public International Law (FPU Scholarship awarded by the Spanish Ministry of Education, ref. FPUi6/o3446), Universidad de Córdoba (eduardo.jimenez.pineda@uco.es). The author would like to thank his mentor, Professor Rafael Casado Raigón, as well as the editorial team and anonymous reviewers of the Spanish Yearbook of International Law for the invaluable opportunity and their helpful and fruitful feedback. All websites last accessed on Io October 2018 and translations by the author.

I STS 2546/20I8, 9 July 2018.

2 Both Decisions 2015/1523 and 2015/160I, establishing provisional measures in the area of international protection for the benefit of Italy and Greece, are no longer in force. Their dates of end of validity were 17 September 2017 and 26 September 2017 , respectively. 
the response to "the critical need to show solidarity towards Italy and Greece and to complement the actions taken so far to support them with provisional measures in the area of asylum and migration." For this purpose, the Decisions created a procedure for the relocation by 26 September 2017 of 120.000 asylum seekers arrived in Italy and Greece to other Member States in the manner established in the Annex of the Decision 2015/160I. ${ }^{4}$ Concretely, in accordance with the system established by both Decisions, Spain was obliged to relocate 19.449 asylum seekers (13.086 applicants for international protection coming from Greece and 6.363 among those who came from Italy), of which, on 4 March 20r8, the Spanish State has just offered 2.500 places for the resettlement of the refugees and effectively relocated 235 people from Italy and I.I24 from Greece.5 Nevertheless, as the Supreme Court points out, the insufficient cooperation between all EU Member States on the relocation of the refugees as well as the lack of response by Italy and Greece to the Spanish requests should be considered, too. ${ }^{6}$

\section{(B) THE JUDGMENT}

(I) Facts and Parties' arguments

By means of an appeal to the Supreme Court, the Associació de support a stop mare mortum sought Spain to immediately comply with its obligations of relocating the asylum seekers in accordance with the Council Decisions (EU) 2015/1523 and 2015/160I. Besides, the appellant asked the adoption of provisional measures in that regard. However, the Supreme Court denied that last possibility throughout the Writ of 17 October 2017?

On the one hand, the claiming association argued that, according to the legal system established by the Decisions, Spain has two obligations. Firstly, a final obligation to take the total quota of asylum seekers in. Secondly, a regular obligation consisting of offering relocation places, approving the lists of refugees and accepting the relocated people within some particular periods. ${ }^{8}$ Both obligations shall be fully, progressively, immediately and urgently met since the Decisions ordered the relocations to be forthwith carried out, 9 being that an order completely enforceable before a court due to the general principles of, among others, loyal cooperation

\footnotetext{
Council Decision (EU) 20I5/I523, whereas (considerando) paragraph I3.

Council Decision (EU) 2015/1601, article four.

STS 2546/2018, supra n. I, I6 $6^{\text {th }}$ legal basis (fundamento de Derecho).

Ibid.

Writ TS, 17 October 2017.

8 STS 2546/20I8, supra n. I, second fact (antecedente de becho).

9 Concretely, the appellant argued that "...el mandato [debe] llevar a cabo la reubicación asignada lo antes posible' o 'o más rápidamente posible”, ibid.
} 
between the Member States and the European Union, and solidarity in the fields of immigration and asylum.

The principle of solidarity is a well-established principle of the European Union Law, being the EU's Common European Asylum System (hereinafter, CEAS) even described as a 'common area of protection and solidarity' and foreseen, for the policies on border checks, asylum and immigration, in article 80 of the Treaty on the Functioning of the European Union (hereinafter, TFEU)..$^{\circ}$ As professor Abrisketa Uriarte pointed out, in the Judgment of the Court of Justice of the European Union of 6 September 2017 (addressed below) the interpretation of the principle of solidarity was reduced to 'merely a symbolic status', probably because of lack of preciseness of the principle in its regulation of article 80 TFEU and as such the Court avoided to make a very detailed interpretation of the scope of this principle.II Interestingly, the principle of solidarity is not included in article 2 of the Treaty of the European Union within the list of values on which the Union is founded, such as respect for human dignity, freedom, democracy, equality, the rule of law and respect for human rights, including the rights of persons belonging to minorities, but however that article refers solidarity to prevail between women and men in the society of the EU Member States. Doubtlessly, solidarity is a founding principle of the EU legal order as well as a structural element of the European integration project despite the lack of a single notion of the solidarity principle applicable to the EU asylum policy.

Nonetheless, Spain would not have complied with those obligations, having offered only the I2.85\% of the relocation places and having effectively relocated just the $6.46 \%$ of the asylum seekers. On the basis of the aforementioned reasons, the appellant requested the Supreme Court to adjudge and declare illegal the rejection by administrative silence of the previous request, in addition to the breach by the Spanish Government of its obligations under the Council Decisions (EU) 2015/1523 and 2015/160I and, finally, to order the Government of Spain to immediately and urgently comply with the aforesaid obligations..$^{\text {I2 }}$

On the other hand, the State Administration argued basically the lack of the appellant association of a collective legitimate interest to appear before the court because the association,

ro E.L. Tsourdi, 'Solidarity at work? The prevalence of emergency-driven solidarity in the administrative governance of the Common European Asylum System', 24 Issue 5 Madstricht Journal of European and Comparative Law (2017) 667-686. Concretely, article 80 reads as follows 'the policies of the Union set out in this Chapter and their implementation shall be governed by the principle of solidarity and fair sharing of responsibility, including its financial implications, between the Member States. Whenever necessary, the Union acts adopted pursuant to this Chapter shall contain appropriate measures to give effect to this principle.'

II J. Abrisketa Uriarte, 'La reubicación de los refugiados: un déficit de solidaridad y una brecha en la Unión Europea. Comentario a la Sentencia del Tribunal de Justicia de 6 de septiembre de 2017, asuntos C-643/15 y C647/I5 Hungría y Eslovaquia contra el Consejo', 44 Revista General de Derecho Europeo (2018) I25-154, at I26, I38 and 153 .

I2 STS 2546/20I8, supra n. I, second fact. 
allegedly, did not mention any reference regarding that legitimacy. According to the State Attorney, who appeared on behalf of the Government of Spain, the relocation aimed by the association was generical and impersonal based on an alleged breach of the Constitution without any concrete reference in relation to that legitimacy. ${ }^{13}$ Therefore, the State Attorney sought the appeal dismissed because the appeal lacked any legal foundation. In view of the State Attorney, Spain was carrying out all the necessary proceedings to ask and relocate the asylum seekers allocated to Spain in spite of the complexity of the procedure as a result of the need for Spain to verify which people of the quota fulfil the requirements laid down to be considered as refugees. ${ }^{14}$ Finally, the State Attorney, taking into account the absence of precedents in the domestic and European jurisprudence, pointed out the alternative for the Court to seek a preliminary ruling before the Court of Justice of the European Union in order to set the way to address this legal issue in the future..$^{I 5}$ Nevertheless, it is worth reminding the existence of the already mentioned 6 September 2018 Judgment given by the Court of Justice of the European Union, which would indeed reject the argument of the State Attorney based on the absence of any precedent in the European jurisprudence.

\section{(2) Merits}

The Chamber of the Supreme Court starts addressing the case refusing the arguments employed by the State Attorney suggesting the Court to seek a preliminary ruling in addition to the argument of the European Commission as the competent to initiate infringement proceedings in its condition of guardian of the Treaties. ${ }^{16}$ In this sense, the Chamber considered itself as competent to control the activity of the national Administration in the compliance and execution of the European Union's obligations. ${ }^{17}$ Notwithstanding the European Commission's task to supervise the observance of the European Union Law, the Commission has a significant discretionary power to bring infringement proceedings before the Court of Justice of the European Union. ${ }^{18}$

(a) The relocation

Regarding the binding nature of the Decisions adopted in order to relocate the asylum seekers arrived in Italy and Greece, the Supreme Court affirms their mandatory nature in addition to their direct effect..$^{19}$ Accordingly, the Supreme Court is of the understanding that the domestic

\footnotetext{
3 STS 2546/20I8, supra n. I, third fact.

I4 Ibid.

Is STS 2546/20I8, supra n. I, third legal basis.

I6 STS 2546/20I8, supra n. I, fourth legal basis.

${ }_{17}$ STS 2546/20I8, supra n. I, fifth legal basis.

I8 Ibid.

19 STS 2546/20I8, supra n. I, sixth legal basis.
} 
courts are able to control the enforceability of the Decisions without contradicting the powers and competences of the European Commission to seek an infringement proceeding against a Member State..$^{20}$ In this case, that proceeding has not been triggered against Spain and hence the Supreme Court can examine and consider the requests and claims of the appellant. Otherwise, whether an infringement proceeding would be pending, to trigger the national jurisdiction would be acceptable since it is the only way for individuals to assert their rights, even though the national jurisdictions should wait the Court of Justice's judgment in order to solve the case in accordance with this last one's decision. ${ }^{21}$ Consequently, the Supreme Court refuses to submit a question for a preliminary ruling to the Court of Justice in considering that possibility as an optional power belonging to the national judge. ${ }^{22}$

Along the two following legal basis of the judgment (eighth and ninth FD), the Supreme Court reproduces some relevant provisions of the two Decisions (EU) 2015/1523 and 2015/160I establishing provisional measures in the area of international protection for the benefit of Italy and of Greece. Firstly, the Supreme Court mentions article 5 of the Decision (EU) 2015/I523, which establishes the relocation procedure, being relevant for this task to hand its paragraph seven, containing that provision the possibility for Member States to "refuse to relocate an applicant only where there are reasonable grounds for regarding him or her as a danger to their national security or public order or where there are serious reasons for applying the exclusion provisions set out in Articles I2 and 17 of Directive 2011/95/EU."23 Secondly, the Decision (EU) $2015 / 160$ is thoroughly explained by the Supreme Court reproducing its I3 provisions. For this paper's purposes, articles four and six are particularly interesting. The first paragraph of the article 4, intitled "Relocation of 120000 applicants to Member States", establishes that "I20 000 applicants shall be relocated to the other Member States as follows: (a) 15600 applicants shall be relocated from Italy to the territory of the other Member States in accordance with the table set out in Annex I; (b) 50400 applicants shall be relocated from Greece to the territory of the other Member States in accordance with the table set out in Annex II; (c) 54000 applicants shall be relocated to the territory of the other Member States, proportionally to the figures laid down in Annexes I and II, either in accordance with paragraph 2 of this Article or through an amendment of this Decision [...]."24 From this provision, the compulsory and mandatory nature of the obligation is remarkable.

(b) The rights of the applicants for international protection

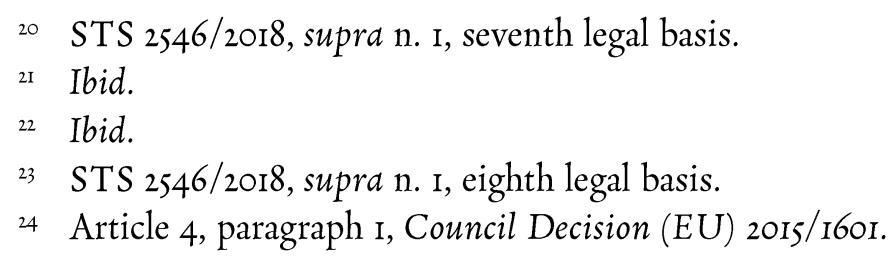


On the other hand, the article six of the Decision 2015/160I, intitled "Rights and obligations of applicants for international protection covered by this Decision", reads as follows:

"I. The best interests of the child shall be a primary consideration for Member States when implementing this Decision; 2. Member States shall ensure that family members who fall within the scope of this Decision are relocated to the territory of the same Member State; 3. Prior to the decision to relocate an applicant, Italy and Greece shall inform the applicant in a language which the applicant understands or is reasonably supposed to understand of the relocation procedure as set out in this Decision; 4. When the decision to relocate an applicant has been taken and before the actual relocation, Italy and Greece shall notify the person concerned of the decision to relocate him in writing. That decision shall specify the Member State of relocation; 5. An applicant or beneficiary of international protection who enters the territory of a Member State other than the Member State of relocation without fulfilling the conditions for stay in that other Member State shall be required to return immediately. The Member State of relocation shall take back the person without delay."

This article is the sole in both Decisions dealing with the rights of the asylum seekers. ${ }^{25} \mathrm{It}$ seems a kind of summary of the right of asylum regulation that is mostly, as it is well-known, customary international law. From this provision, the prior interest of the child clearly stands out. Besides, the relocation of families in the same Member State is the second element to consider in order to carry out the relocations. Finally, the need to ensure the fulfilling of the conditions by the applicants of international protection can be pointed out, too. Apart from being the sole provision of the Decisions addressing in somehow the international law of protection, this legal basis constitutes, ${ }^{26}$ surprisingly, the only reference made by the Supreme Court through the entire judgment to this important field of international law, specially taking into consideration the fundamental matter of the decision, namely: the obligation to receive and relocate the refugees arrived in Italy and Greece. Therefore, to clarify the legal distinction between the regime of refugees and economic migrants could have been convenient since not all the applicants for international protection ought to have the same treatment. Nevertheless, it can also be argued that explanation is not necessary in this judgment because the obligation that Spain have to comply with is just in relation to the asylum seekers arrived in Italy and Greece, whom the Decisions' system assume that already fulfil the conditions to benefit of international protection.

(c) The nature of provisional measures

In addition, along the tenth legal basis of the judgment, the Supreme Court brings up the Judgment given by the Court of Justice of the European Union on 6 September 2017 addressing

${ }_{25}$ In this regard, see S. Peers, 'Relocation of Asylum-Seekers in the EU: Law and Policy', EU Law Analysis, published on 24 September 2015.

26 STS 2546/20I8, supra n. I, ninth legal basis. 
the content of the Decision 2015/160I in response to its contestation by some EU Member States. ${ }^{27}$ The interpretation of the Decision's content given by the Court of Justice, logically, is prominently considered by the Supreme Court. In its reasoning, the Supreme Court repeats some of the most relevant legal arguments of the Court of Justice's Judgment about the context, history, and content of the contested Decision. ${ }^{28}$

Moreover, the Supreme Court broaches several findings of the Judgment of the Court of Justice. ${ }^{29}$ Regarding the "[t]he first part of the Slovak Republic's fifth plea and Hungary's second plea, alleging that the contested decision is not provisional and that its period of application is excessive", $3^{\circ}$ the Court of Justice clarified that "choice of a period of application of 24 months is justified in view of the fact that the relocation of a large number of persons, such as that provided for in the contested decision, is an unprecedented and complex operation which requires a certain amount of preparation and implementation time, in particular as regards coordination between the authorities of the Member States, before it has any tangible effects." ${ }^{\text {I }}$

Concerning "[t]he second part of the Slovak Republic's fifth plea, alleging that the contested decision does not satisfy the conditions for the application of Article 78(3) TFEU [Treaty on the Functioning of the European Union]", namely "that the Member State benefiting from the provisional measures must be confronted by 'an emergency situation characterised by a sudden inflow of nationals of third countries", ${ }^{32}$ the Court of Justice declared that "[i]t is apparent from recitals $\mathrm{I} 2, \mathrm{I} 3$ and 26 of the contested decision and from the statistical data mentioned in those recitals that a sufficiently close link has been established between the emergency situation in Greece and Italy, namely the significant pressure on the asylum systems of those Member States, and the inflow of migrants throughout 2015, in particular in July and August of that year." ${ }_{33}$

Finally, the last finding of the Court of Justice's judgment brought up by the Spanish Supreme Court is related to the "Slovak Republic's sixth plea, in so far as it alleges that the contested decision is not appropriate for attaining the objective which it pursues." ${ }^{34}$ In that regard, the Court of Justice declared that, since "[...]the legality of an EU act cannot depend

\footnotetext{
27 Judgment of the Court (Grand Chamber) of 6 September 2017, Slovakia v Council and Hungary v Council, C-643/15 and C-647/15, EU:C:2017:631.

${ }_{28}$ STS 2546/20I8, supra n. I, tenth legal basis.

29 STS 2546/20I8, supra n. I, II ${ }^{\text {th }}$ legal basis.

30 Italic emphasis in the original.

${ }^{3 \mathrm{I}}$ Judgment of the Court (Grand Chamber) of 6 September 20I7, Slovakia v Council and Hungary v Council, supra n. 27 , para. 97.

$32 \quad$ Ibid, para. 107

33 Ibid, para. 126.

34 Italic emphasis in the original.
} 
on retrospective assessments of its efficacy" 35 and "[...] when the Council adopted the mechanism for the relocation of a large number of applicants for international protection, it carried out, on the basis of a detailed examination of the statistical data available at the time, a prospective analysis of the effects of the measure on the emergency situation in question, ${ }^{36}$ the "[...] analysis does not appear manifestly incorrect." ${ }^{37}$ Regardless, the Court of Justice importantly suggests that "[...] the small number of relocations so far carried out pursuant to the contested decision can be explained by a series of factors that the Council could not foresee at the time when the decision was adopted, including, in particular, the lack of cooperation on the part of certain Member States. ${ }^{38}$

In view of the foregoing, the Supreme Court begins to decide on the merits of the case. For this purpose, the Supreme Court upholds that the Decisions contain "provisional measures" in the sense of article 78 (3) of the TFEU because the Decision (EU) 2015/160I has a period of validity of 24 months according to article 13 thereof. 39 Although that "provisional measure" nature of the Decision should, in view of the State Attorney, make the Court to reject as unfounded the appeal, the Supreme Court declares, referring the words of the European Commission in a communication of $\mathrm{I} 2$ April 2017,40 that "[...]more efforts are needed from all Member States to ensure that all people eligible are relocated over the coming months [...]" and as such "[...]if Member States do not increase their relocations soon, the Commission will not besitate to make use of its powers under the Treaties for those which bave not complied with the Council decisions, noting that the legal obligation to relocate those eligible will not cease after September $[\ldots] .{ }^{\prime \prime 4}$

\section{(d) The relocation quotas}

Consideration is given by the Supreme Court to the relocation quotas assigned to Spain within a period of 24 months -since 25 September 2015 until 26 September 2017- by virtue of Annexes I and II of the Decision 2015/160I, which allocated to Spain a quota of $12,15 \%$ of the total of relocations..$^{42}$ As a consequence of article 4 of the Decision 20I5/160I, Spain shall offer places

\footnotetext{
35 Judgment of the Court (Grand Chamber) of 6 September 20I7, Slovakia v Council, supra n. 27, para. 22I.

36 Ibid, para. 222.

37 Ibid.

38 Ibid, para. 223.

39 STS 2546/20I8, supra n. I, I2 ${ }^{\text {th }}$ legal basis. The article $78(3)$ TFEU establishes that " $\left.\mathrm{i}\right] \mathrm{n}$ the event of one or more Member States being confronted by an emergency situation characterised by a sudden inflow of nationals of third countries, the Council, on a proposal from the Commission, may adopt provisional measures for the benefit of the Member State(s) concerned. It shall act after consulting the European Parliament."

${ }^{40}$ European Commission, 'Eleventh report on relocation and resettlement', $\mathrm{COM}(2017)$ 2I2 final, published I2 April 2017.

${ }^{41}$ S TS 2546/20I8, supra n. I, I $3^{\text {th }}$ legal basis. Italic and bond emphasis in the original text of the Judgment.

${ }^{42}$ STS 2546/20I8, supra n. I, I $6^{\text {th }}$ legal basis.
} 
and relocate 8.023 asylum seekers (1.896 from Italy and 6.127 from Greece) and, according to its paragraphs I (c) and 2, other 6.564 people should have been relocated in Spain between 26 September 2016 and 25 September 2017 (1.55I from Italy and 5.013 from Greece). In addition, 2.917 asylum seekers from Italy and 1.945 from Greece ought to be relocated in Spain in accordance with article 4 (a) (b) of the Decision 2015/1523.43 It follows that Spain should have effectively offered places and relocated 13.086 asylum seekers from Greece and 6.363 from Italy. In that regard, the Supreme Court remarks that Spain could have reduced the $30 \%$ of its quota, following the article 4.5 of the Decision 2015/160I, but the Spanish State decided not to take that possibility. ${ }^{44}$

In this sense, the fact that the relocation mechanism was already finished up (it came to its end on 26 September 2017) by the time the Supreme Court gave this Judgment (9 July 2018) ought to be taken into consideration. In general, the mechanism was not very successful since instead of 160.000 asylum seekers foreseen by both Decisions of 2015, just 33.846 asylum seekers had been effectively relocated in the European Union as a whole. 45 Nevertheless, the failure of that mechanism to relocate the asylum seekers is not only due to the 'lack of interest' performed by Spain or even more the strong resistance to its implementation conspicuously shown by countries like Hungary, the Czech Republic, Slovakia and Poland, but also the consequence of several factors ${ }^{46}$ namely: $\mathrm{I}$. The lack of the preceptive request made by many asylum seekers in order to avoid the country of destination preestablished by the mechanism in trying to move to countries of their own choice; 2. The EU-Turkey agreement of 2016, whose implementation brought a significant reduction in the number of asylum seekers in Greece; 47 and, 3. The relocations were effectively carried out exclusively when the asylum seekers consented to their transfer to another EU country.

(e) The breach of the obligations to offer places and to carry out the relocation

Thus, the Supreme Court concludes that Spain has breached its obligations to offer places and to effectively carry out the relocations to which it was obliged to. As such, six months later

43 Ibid.

44 Ibid.

45 B. De Witte and E.L. Tsourdi, 'Confrontation on relocation-The Court of Justice endorses the emergency scheme for compulsory relocation of asylum seekers within the European Union: Slovak Republic and Hungary v. Council', 55 Issue 5 Common Market Law Review (2018) I457-I494, at I492-I494.

46 Ibid.

47 As professors De Witte and Tsourdi rightly highlight "I9 March 2016 (the day after the EU-Turkey statement) was de facto considered as a cut-off date for relocation, despite this interpretation going against the text of the emergency relocation decisions" and "hence, all asylum seekers that arrived on the Greek islands still during the application period of the schemes, but after 19 March 2016, were not considered eligible for relocation, regardless of their nationality, and even if they did file asylum claims", ibid. 
than the deadline, the report of the Asylum and Refugee Office (Oficina de Asilo $y$ Refugio) recognizes a compliance percentage less than $\mathrm{I} 3 \%$, likewise, according to that report, on 4 March 2018 Spain had just offered 2.500 places, i.e. a $12,85 \%$ of its total mandatory quota. ${ }^{48}$ Notwithstanding that assertion, the Supreme Court also acknowledges the fact that both Greece and Italy have received requests from Spain to relocate asylum seekers without the compulsory response from those States. Therefore, as mentioned above, that scenario highlights a prominent failure in the fulfilment of the coordination tasks essential for the succeeding of the Decisions. ${ }^{49}$

Indeed, the Spanish State has not fully complied with the European Decisions despite their binding and compulsory legal nature..$^{50}$ The serious administrative difficulties to fulfil those obligations, as the State Attorney emphasised, can under no circumstance mean their exemption since the measures aimed to make flexible the relocation objectives of the Decision have not been neither invoked nor used by the Spanish Government..$^{. I}$ Moreover, the Supreme Court highlights that a general lack of compliance of the aforementioned Decisions does not justify the omissive conduct protested in this appeal..$^{2}$

Finally, the Supreme Court concludes the legal reasoning of the judgment declaring that "the complexity of the relocation process, the need to cooperate of Greece and Italy and the measures to be adopted by the European Institutions oblige, in the Chamber's view, that the declaration of partial breach of the regular obligations of the Decisions results in the sentence for the Spanish State to continue the processing in accordance with the Decisions and with the agreements that in the future the European Institutions may adopt.",53

(3) The Decision

In light of the above, the Fifth Section of the Contentious-Administrative Chamber of the Supreme Court: I) partially upholds the appeal and declares unlawful the rejection by administrative silence of a request of 2I April 2017; 2) partially upholds the request; 3) declares the partial breach by the Spanish State of the administrative obligations established in the Decisions (EU); and, 4) consequently, the Spanish State shall continue the processing [of the applications of international protection from asylum seekers arrived in Italy and Greece] in

\footnotetext{
48 This author has not been able to find the report of the Oficina de Asilo $y$ Refugio mentioned by the Supreme Court in its Judgment.

49 STS 2546/20I8, supra n. I, I6 $6^{\text {th }}$ legal basis.

so STS $2546 / 2018$, supra n. I, I $7^{\text {th }}$ legal basis.

sI Ibid.

52 Ibid.

53 STS 2546/20I8, supra n. I, I $8^{\text {th }}$ legal basis.
} 
accordance with the Decisions and with the agreements that in the future the European Institutions may adopt. The Court did not assign any Party in the proceeding to pay the costs. ${ }^{54}$

\section{(C) CONCLUSION}

The judgment of the Supreme Court analysed along this note concludes succinctly that Spain has failed to duly comply with the Decisions EU 20I5/1523 and 20I5/160I, establishing provisional measures in the area of international protection for the benefit of Greece and Italy, since the Spanish State has just offered less than the $13 \%$ of its relocation quota allocated by those Decisions. Consequently, and in spite of the general lack of cooperation between the EU Member States (including Greece and Italy), Spain shall continue the processing of the applications of international protection made by asylum seekers arrived in Italy and Greece in accordance with the Decisions and with the agreements that in the future the European Institutions may adopt.

This judgment means the first decision given by a domestic court of an EU Member State dealing with the two Council Decisions entered into force in 2015 in order to solve, through relocations of the asylum seekers, the refugee crisis that took place in Italy and Greece due to the massive arrival of refugees to those countries. Besides, this judgment of the Spanish Supreme Court implies an interpretation and, more specifically, application of the Judgment given by the Court of Justice of the European Union answering to the appeal made by the Slovak Republic and Hungary, by means of which the Court of Justice declared the conformity of the Decision 2015/160I with the rules and principles of the European Union Law.

Nevertheless, this judgment could be rather presumptuous taking into account the difficulties of the interpretation of the legal system established by those EU Decisions. Even though their legal binding nature is doubtless, the manner to enforce the obligations therein may not be as easy as the Supreme Court understands. In this sense, it seems a complicated task to identify the refugees who arrived within 2015 in Italy and Greece and to obtain the cooperation of their governments to effectively relocate in Spain the pending number of them to fulfil the mandatory quota. Accordingly, as the State Attorney pointed out, the possibility of the Supreme Court to seek preliminary ruling before the Court of Justice could have been convenient in order to clarify the way to comply with the Decisions and to remind the EU Member States their obligation to cooperate and to relocate their quota of asylum seekers. On the other hand, it can also put into question the intervention of the European Commission, or rather, the lack of its intervention, since regarding such an important issue the Commission should have initiated infringement proceedings before the Court of Justice against those States

54 STS 2546/2018, supra n. I, decision (fallo). 
(including Spain) for their failure to fulfil their obligations in accordance with the Decisions EU 2015/1523 and 2015/160I.

Indeed, the Spanish Supreme Court could have been quite naive trying Spain to solve the huge and severe issue of the refugee's crisis in complying with a legal regimen that has clearly become insufficient and inefficient because of the lack of cooperation between the EU Member States. Nonetheless, it is worth putting into context that any system, even one without structural weaknesses in terms of its capacity, would more likely have been seriously affected and disrupted by the unprecedent influx of arriving migrants which took place in Italy and Greece during 2015. In this sense, the reform of the EU's CEAS has been proposed, whose need was highlighted by that migration crisis. Among the weaknesses of the CEAS, the need of uniform treatment for asylum seekers across the EU is remarkable since the asylum seekers can travel along Europe, in a common space without internal borders, and as such apply for international protection in the country where a higher level of international protection is expected. Consequently, the Council of the European Union is working on seven legislative proposals, 55 made by the European Commission to improve EU asylum rules and system, aimed mainly to "make the system more efficient and more resistant to migratory pressure", "eliminate pull factors as well as secondary movements" and finally "fight abuse and better support the most affected member states" ${ }^{56}$

Importantly, this judgment highlights the Spanish commitment, stated by means of its highest judicial institution, to the Rule of Law and to the European Union legislation and values. Moreover, the current political situation in some countries of the EU with governments clearly against the reception of migrants and refugees, concretely Italy, shows a complicated scenario for the cooperation between Member States and for the complete enforcement of the Decisions' system as well as the forthcoming regulations to collectively address the relocation of the asylum seekers arrived in the European Union.

Finally, the present judgment may bring a hoped judicial development to achieve the effective relocation of the asylum seekers according to the Decisions (and, in general, to the International Law), even though it seems doubtful the judgment could be enforced by the

${ }_{55}$ The seven legislative proposals presented by the Commission aim to: "I. Reform the Dublin system to better allocate asylum applications among member states and to guarantee the timely processing of applications; 2. Reinforce the Eurodac [European Dactyloscopy] regulation to improve the EU fingerprint database for asylum seekers; 3. Establish a fully fledged EU asylum agency; 4 . Replace the asylum procedure directive with a regulation to harmonise EU procedures and reduce differences in recognition rates among member states; 5 . Replace the qualification directive with a regulation to harmonise protection standards and rights for asylum seekers; 6 . Reform the reception conditions directive to ensure that asylum seekers benefit from harmonised and dignified reception standards; and, 7. Create a permanent EU resettlement framework", in Council of the European Union, Reform of EU asylum rules. Original bold emphasis turned into italic emphasis.

56 Ibid. Bold emphasis omitted. 
Spanish Government and it could create a judicial precedent along other EU Member States. Otherwise, it will be the turn for the European Commission, in its condition of guardian of the Treaties, to initiate the diverse proceedings, mainly the infringement ones, to ensure the enforcement of the European Union Law in this field of international protection. 